\title{
Czy wojna nowego typu może być sprawiedliwa?
}

DOI 10.35757/CIV.2015.17.05

Odpowiedź na postawione w tytule pytanie nasuwa się właściwie sama - przecież wojna, a zwłaszcza współczesna, nazywana czasem wojna nowego typu, nie może mieć nic wspólnego ze sprawiedliwością. Spróbujmy się jednak przyjrzeć teorii wojny oraz koncepcji wojny sprawiedliwej wpisanej w międzynarodowy porzadek prawny, aby wskazać nie tyle prosta tezę, ile przede wszystkim argumentację ukazująca, jakie konkretne przemiany w sposobach prowadzenia wojen powoduja, że bardzo trudno zastosować do nich narzędzia wypracowane przez teorię i praktykę prawa międzynarodowego dotyczącego konfliktów zbrojnych.

Tezą artykułu jest twierdzenie, że współczesne relacje międzynarodowe oraz konflikty zbrojne nie moga być ujęte w ramy prawa wojennego i uporzadkowane w odniesieniu do teorii wojny sprawiedliwej. Obserwujemy kryzys idei suwerenności jako idei porządkującej zarówno stosunki wewnętrzne, jak i międzynarodowe, w związku $z$ tym także inne pojęcia odniesione do kategorii suwerenności traca ostrość. Nastapiła zmiana charakteru walczacych stron, obok wojsk wystawianych przez państwa pojawiły się różnego rodzaju mniej lub bardziej określone podmioty, walczace grupy, ochotnicy, najemnicy, stronnicy walczacy na terenie obcych państw. Zmiana ta spowodowała zmianę charakteru wojny. Poprzednio była ona zasadniczo jawnym starciem pomię-

Agnieszka Nogal - doktor habilitowany, pracuje jako adiunkt w Zakładzie Filozofii Polityki Instytutu Filozofii Uniwersytetu Warszawskiego. 
dzy armiami oficjalnie reprezentującymi państwa. Obecnie stała się nie do końca jawna konfrontacją sił popieranych przez rozmaite, nie zawsze także jawne strony konfliktu. Wojna przeszła więc $z$ obszaru sfery publicznej do półjawnej strefy pomiędzy tym, co prywatne, a jednak znaczace dla porzadku politycznego, i tym, co publiczne.

Już sam opis zachodzących przekształceń może wywołać opór teoretyków związanych $z$ innymi ujęciami wojny. Wątpliwości moga wiązać się tym bardziej $z$ proponowanym $w$ niniejszym tekście powrotem do koncepcji wojny sprawiedliwej. Najprostszym rozwiazaniem wydaje się bowiem odrzucenie tej koncepcji. Prawo międzynarodowe - zwłaszcza ta jego część, która odnosi się do wojen - wymaga jednak oparcia. Oparciem tym współcześnie nie może już być żadna konkretna koncepcja metafizyczna. Istotne pozostało jednak zachowanie porzadku samego prawa. Jeden $z$ teoretyków wojny sprawiedliwej John Rawls wskazał, że teoria wojny sprawiedliwej może być takim oparciem, gdy usuniemy jej metafizyczne uzasadnienia. Teoria wojny sprawiedliwej wymaga jednak określonych podmiotów zbiorowych. I te, jak się wydaje, łatwiej dookreślić na nowo, niż odnaleźć inne oparcie dla prawnomiędzynarodowej ochrony ofiar konfliktów zbrojnych.

\section{Kryzys suwerenności jako idei porządkującej stosunki wewnętrzne i międzynarodowe}

Obserwując współczesne konflikty zbrojne, można zauważyć, że wymykaja się one jednoznacznej kontroli państw. Wystarczy wskazać na dwa przykłady, takie jak konflikt na Ukrainie czy wojna w Syrii, żeby zobaczyć, że samo wskazanie walczących stron może być przedmiotem długiej i zawiłej dyskusji. Tymczasem w stosunkach międzynarodowych od 1648 roku obowiazywał system westfalski, którego integralnym elementem było bezwarunkowe uznanie suwerenności państwowej. Pojęcie suwerenności porządkowało 
od tego czasu ład zarówno wewnętrzny, jak i międzynarodowy. Odnosiło się do dwóch poziomów - pierwszy $z$ nich wyznaczał monopol na stanowienie prawa, drugi - stanowienie o wojnie i pokoju. Trzeba zauważyć, że pojęcie suwerenności nie opisuje ani nie porządkuje już przestrzeni prawnej. Państwa utraciły przynajmniej częściowo swą suwerenność w wymiarze militarnym - jej miejsce zajęły bloki obronne i współpraca militarna, suwerenność wewnętrzna zaś, pojmowana jako monopol na stanowienie prawa, ustapiła miejsca współzależności i pluralizmowi prawnemu, w którym obok prawa państwowego funkcjonuje również prawo ponadpaństwowe. Znacznie bardziej jednak niszczące okazało się wkroczenie hegemonii i relacji siłowych do struktur politycznych. Relacje te przyczyniły się bowiem do dalszego zatarcia się granic suwerenności zarówno wewnętrznej, jak i zewnętrznej.

W relacjach wewnętrznych hegemonia została uznana za źródło ładu i prawa już przez Carla Schmitta. W odniesieniu do stosunków międzynarodowych Schmitt jednak pozostał zwolennikiem traktowania podmiotów tych stosunków jako równorzędnych. W porządku wewnętrznym, zdaniem Schmitta, państwo tworzyło się $\mathrm{w}$ ten sposób, że jedna $z$ grup zdobywała pozycję dominująca i narzucała własne rozwiąania pozostałym grupom, tworzac konstytucje i porządek prawny. W wymiarze międzynarodowym jednak państwa pozostawały równorzędne. Elementem tej równości była także możliwość konfliktu. Wedle niemieckiego jurysty, wojna była czymś nieuchronnie wpisanym w działanie zbiorowości, które toczyły między soba spory o dobra materialne lub duchowe, takie jak terytorium, zasoby materialne, surowce naturalne, wszelkie wytwory oraz populacja ${ }^{1}$. Wygrana wojna pozwalała, zdaniem Schmitta, nie tylko przejąć kontrolę nad zasobami materialnymi, ale także narzucić innej zbiorowości sposób życia i wartości uznawane za obowiąujące i właściwe przez stronę wygrana.

\footnotetext{
1 Zob. C. Schmitt, Teologia polityczna i inne pisma, przekład M. Cichocki, Znak, Fundacja Batorego, Kraków 2000.
} 
W ujęciu Hansa Morgenthaua, zniknęła równość państw. Zarówno przestrzeń wewnętrzna wspólnoty politycznej, jak i zewnętrzna zostały uznane za obszar walki o hegemonię ${ }^{2}$. Wewnatrz ścierały się zbiorowe tożsamości i grupy, $z$ których jedna zdobywając dominację, narzucała własne reguły pozostałym. Także przestrzeń międzynarodowa została uznana za obszar walki o dominację pomiędzy zbiorowościami. W walce tej zasadnicze znaczenie miała liczebność i relatywna siła. Podobnym szlakiem argumentacji podażyła Chantal Mouffe ${ }^{3}$. W efekcie - zbliżając się do współczesności, uzyskaliśmy teoretyczne ujęcie stosunków zarówno wewnętrznych, jak i zewnętrznych, opartych na idei hegemonii, a nie jak wcześniej, suwerenności. Wewnętrzna walka o hegemonię nałożyła się na walkę o hegemonię międzynarodową. Nierówne sobie państwa rywalizowały o hegemonię, wchodzac w sojusze $z$ innymi i tworząc bloki państw. Nie bez znaczenia była także walka o wewnętrzną hegemonię, w której ścierały się zbiorowe tożsamości i grupy. Także ta wewnętrzna walka stała się elementem przestrzeni międzynarodowej. Strony konfliktów wewnętrznych mogły być bowiem wspierane przez zewnętrzne podmioty. Tworzył się $\mathrm{w}$ ten sposób nieprzejrzysty obraz nakładających się na siebie wewnętrznych i zewnętrznych konfliktów, których nie można było uzgodnić, a co najwyżej zrównoważyć. Siły wewnętrzne, na przykład mniejszościowe, mogły wchodzić w strategiczne sojusze $z$ siłami dominujacymi $\mathrm{w}$ innych państwach. Logika ta prowadziła do całkowitego chaosu, który wyzwalał jedynie siły dalszych podziałów i rozdziałów, sojuszy i niejawnych, podskórnych działań i niewidocznych przegrupowań, powodujących coraz dalszą fragmentację wewnętrzną i wzmaganie potencjału agresji. Jawność relacji została zastąpiona przez niejawność, równość - przez wszechobecne dążenie do dominacji. Niestety ten język opisu teoretycznego na początku XXI wieku zaczął coraz bardziej przystawać do obrazu współczesnych wojen.

\footnotetext{
2 Zob. H.J. Morgenthau, Polityka między narodami. Walka o potęge i o pokój, przekład R. Włoch, Wydawnictwo Difin, Warszawa 2010.

${ }_{3}$ Zob. Ch. Mouffe, Polityczność. Przewodnik Krytyki Politycznej, przekład J. Erbel, Wydawnictwo Krytyki Politycznej, Warszawa 2008.
} 
Zasada prowadzenia wojny w przestrzeniach opisywanych i porządkowanych zgodnie $z$ kategorią suwerenności była jej jawność, umundurowanie, specjalne oznaczenia odróżniające walczące strony. Zastapieniu zasady równości suwerennych stron konfliktu zasada hegemonii towarzyszyło zatarcie obrazu wojny. Miejsce walczacych żołnierzy zajęli przedstawiciele sił specjalnych, którzy dażyli do wtopienia się w lokalną ludność i prowadzenia wojny metodami, które wcześniej były zastrzeżone dla partyzantki.

Wojna przesunęła się $z$ obszaru jawnego, na który wskazywała związana $z$ wojna metafora "teatru działań wojennych" do obszaru półjawnego. Straciła też swój wyróżniony obszar nazywany wcześniej teatrem działań. Przyczyniły się do tego techniczne zmiany w uzbrojeniu, które umożliwiły prowadzenie wojny na odległość, posługiwanie się samolotami, dronami oraz rakietami dalekiego zasięgu. Przeciwko technice zaś stanęły do walki niejawne struktury półcywilnych sił. W ostatnich konfliktach przeciwnik stosował strategie z zakresu „uderz i zniknij”, działając w sposób, który uniemożliwiał niejednokrotnie zdefiniowanie przestrzeni walk. Używana broń i systemy komunikacyjne, poprzez swoja prostotę czy wręcz prymitywizm, okazywały się zaskakująca przeciwwaga dla technicznie zaawansowanych sił interwencyjnych.

W zwiazku z zanikiem teatru działań wojennych izolowanie obszarów zdestabilizowanych wojna stało się praktycznie niemożliwe, zwłaszcza że nowoczesne środki techniczne wpłynęły na upowszechnienie się terroryzmu. Wojna zatem zaczęła w pośredni i coraz częściej bezpośredni sposób przenikać do „świata pokoju”, w którym także zaczęła narastać gotowość do sięgania po przemoc.

Nowe zjawiska zostały w teorii wojny nazwane wojna nowego typu. Najbardziej znana charakterystykę wojen nowego typu przedstawiła w swych pracach Mary Kaldor ${ }^{4}$. W książce zatytułowanej Nowe $i$ stare wojny określiła ona wojny nowego typu mianem wojen, gdyż miały nadal charakter polityczny, były jednak

${ }_{4}$ M. Kaldor, New \& Old Wars. Organized Violence in a Global Era, Stanford University Press, Stanford 1998. 
„nowe”, gdyż zacierały granice pomiędzy wojną a przestępstwem. Często, jej zdaniem, służyły prywatno-ekonomicznym celom i odzwierciedlały zmieniajacy się charakter relacji ekonomicznych. Fragmentaryzacja oraz nieformalny charakter wojen nowego typu odpowiadały zmianom, które zachodziły w sferze ekonomii, gdzie również następowała fragmentaryzacja oraz wzrost znaczenia nieformalnych relacji. Miejsce narodowej sformalizowanej ekonomii $z$ jej naciskiem na produkcję przemysłową i regulacje państwowe zajęła nowa zglobalizowana ekonomia wraz $z$ jej nieformalnym charakterem i zależnościami zazębiającymi się ponad poziomami państw ${ }^{5}$. Wojny nowego typu były prowadzone przez różnorodne kombinacje podmiotów zarówno państwowych, jak i niepaństwowych oraz prywatnych. Pozostały wprawdzie lokalne i czasem były określane mianem „nisko intensywnych” (low intesity), ale angażowały całe sieci i miały charakter globalny. Wykorzystywały nowoczesne techniki informacyjne, w tym cyberprzestrzeń, ale sięgały także po elementy premodernistyczne, które w zderzeniu $z$ nowoczesnymi zabezpieczeniami okazywały się nad wyraz skuteczne.

Wojny nowego typu towarzyszyły przy tym procesowi globalizacji i wielopoziomowym sieciom, które tworzyły się pomiędzy podmiotami różnego typu. Byli tam obecni międzynarodowi sprawozdawcy, dziennikarze, grupy międzynarodowych najemników, doradców wojskowych, ochotników $z$ diaspory i tym podobne. Mary Kaldor nie podkreśla tego elementu, ale warto zauważyć, że wojnom nowego typu towarzyszyła zanikająca państwowa suwerenność. Erozja suwerenności dokonała się zarówno od góry poprzez konsolidację i umiędzynarodowienie sił zbrojnych $\mathrm{w}$ blokach militarnych, jak i od dołu poprzez prywatyzację wojny, która przestała być przemoca legitymizowana jedynie przez państwa. W ten sposób opis wojen nowego typu, który odnajdujemy u Mary Kaldor, odzwierciedlał opis relacji międzynarodowych kreślonych zgodnie ze słabnącym znaczeniem suwerenności.

5 Eadem, New \& Old wars..., Stanford University Press, Stanford 2007 (wyd. 2), s. 111. 
W swej rekonstrukcji wojen nowego typu Mary Kaldor wskazała na zmiany, jakie zaszły w odniesieniu do podmiotów, celów, metod prowadzenia i form finansowania. Wszystkie te zmiany wskazywały na tracenie porzadkującego znaczenia, jakie dotychczas miała kategoria suwerenności ${ }^{6}$.

Podmioty. Tradycyjne wojny były prowadzone przez regularne armie państwowe, wojny nowego typu włączały niepaństwowe podmioty: najemników, wojowników religijnych, siły paramilitarne itp.

Cele. Wojny starego typu były prowadzone w imię geopolitycznych interesów lub ideologii, nowe wojny za cele uznały kwestie związane ze zbiorową tożsamością etniczną, religijną bądź plemienna. Polityka prowadzona w imię celów tożsamościowych miała inna logikę niż polityka realizujaca cele geopolityczne lub ideologiczne. Celem tradycyjnym był dostęp do władzy dla konkretnych grup, narzędziem - mobilizacja na poziomie państwowym. Pojawienie się polityki tożsamości, związane $z$ nowymi technologiami komunikacyjnymi, zatarło znaczenie państwowych granic. Polityczna mobilizacja wokół tożsamości stała się jednocześnie raczej celem niż narzędziem wojny.

Metody. W wojnach starego typu wojnę prowadzono poprzez zagarnianie terytorium w czasie bitew. Walczace strony miały hierarchiczną strukturę, w której był jasno określony porządek podejmowania decyzji. W wojnach nowego typu bitwy bywały rzadkie, a terytorium opanowywano poprzez środki polityczne oraz kontrole nad populacją. Nowa technika było usuwanie siłą tych osób, których tożsamość różniła się od dominującej, a przemoc stosowano głównie wobec cywilów. Znikał hierarchiczny porządek podejmowania decyzji.

Formy finansowania. Wojny tradycyjne finansowane były zazwyczaj przez państwa dzięki podatkom zbieranym od obywateli. Wojny nowego typu często wspierane były przez prywatnych spon-

6 Rekonstrukcja wojny nowego typu za M. Kaldor, In Defence of New Wars, Stability: International Journal of Security and Development, 2013 - stabilityjournal.org, http://www.stabilityjournal.org/articles/10.5334/sta.at/ [dostęp: 30 grudnia 2015]. 
sorów, diaspory czy działania przestępcze, takie jak: porwania, wymuszenia, szmugiel ropy, diamentów, narkotyków itp. O ile wojny starego typu wymagały scentralizowanych ekonomii, a wojna mobilizowała cała populacje państwa, o tyle nowe wojny angażowały rozmaite podmioty ekonomiczne, niezorganizowane i powiazane z różnymi grupami, często w różnych częściach globu.

Te i inne cechy współczesnych konfliktów zbrojnych doprowadziły nie tylko Mary Kaldor do wniosku, że stanowią one nowa jakość. Nazwane zostały „wojnami nowego typu”, „nowymi wojnami”, „wojnami brudnymi" i uznane za odrębny fenomen zarówno w zakresie celów wojny, jak i metod jej prowadzenia (na trzech poziomach: strategicznym, operacyjnym i taktycznym). Frank Hoffman charakteryzował nowe wojny jako „wojny hybrydowe”7. John Mueller opisywał je jako „kryminalne” i prowadzone przez małe grupy ${ }^{8}$. Martin Shaw określał je mianem wojen zdegenerowanych i wskazywał na broń, która przyczyniała się do masowej likwidacji całych populacji ${ }^{9}$. Inni zwolennicy użycia terminu "wojny nowego typu" to Herfried Münkler ${ }^{10}$, Martin van Creveld ${ }^{11}$ i Mohamed Mahmoud ${ }^{12}$.

\section{Koncepcja wojny sprawiedliwej w nowym kontekście}

Główny problem $z$ wojnami nowego typu nie polegał jednak na wszystkich przedstawionych wyżej przemianach, ale na tym, że nie można było do nich zastosować ugruntowanej w prawie międzynarodowym koncepcji wojny sprawiedliwej. Tymczasem teoria wojny

\footnotetext{
7 F. Hoffman, Conflict in the 21st Century. The Rise of Hybrid War, Potomac Institute for Policy Studies, Arlington 2007.

8 J. Mueller, The Remnants of War, Cornell University Press, Ithaca - London 2004.

9 M. Shaw, War and Genocide. Organised Killing in Modern Society, Polity, Oxford 2003.

${ }^{10}$ H. Münkler, The New Wars, przekład Patric Camiller, Polity, Oxford 2005.

${ }^{11}$ M. van Creveld, The Transformation of War. The Most Radical Reinterpretation of Armed Conflict Since Clausewitz, Free Press, New York 1991.

${ }^{12}$ M. Mahmoud, Understanding Al Qaeda. The Transformation of War, Pluto Press, London 2006.
} 
sprawiedliwej tkwiła $\mathrm{u}$ podstaw prawa międzynarodowego porząkującego konflikty zbrojne. Pojęcie wojny sprawiedliwej określało normatywne ujęcie wojny, która mogła być wojna niesprawiedliwa, a więc naruszająca porządek prawa międzynarodowego, bądź sprawiedliwa, wypełniająca normy prawne. Jest to obecnie dominujące stanowisko wobec konfliktów zbrojnych, wedle którego wojny winny podlegać porządkowi wyznaczonemu przez prawo. Prawo określało warunki przystapienia do wojny (ius ad bellum), prowadzenia wojny (ius in bellum) oraz warunki późniejszego pokoju (ius post bellum). Zanim jednak wojna stała się przedmiotem regulacji prawnomiędzynarodowych, w ramach myśli chrześcijańskiej narodziła się filozoficzna koncepcja wojny sprawiedliwej, której głównymi autorami byli Augustyn i Tomasz z Akwinu. Koncepcja ta wyznaczyła filozoficzno-pojęciowe ramy, które przybrały $z$ czasem formę regulacji prawnomiędzynarodowych, racje przedstawione przez twórców tej koncepcji do dziś zaś pozwalaja zrozumieć kształt przyjmowany przez prawo międzynarodowe. I choć po II wojnie światowej tkwiąca u podstaw prawa metafizyka została odrzucona, to regulacje prawne pozostały i nabrały znaczenia. Dopiero współcześnie wojny nowego typu, niszcząc ontologię polityczną ufundowaną na wspólnocie politycznej, spowodowały głęboki kryzys porządku prawa międzynarodowego.

Można uznać, że pojęcie sprawiedliwości do stosunków międzynarodowych wprowadziła wraz $z$ koncepcja prawa naturalnego myśl chrześcijańska. $Z$ tego powodu, teoria wojny sprawiedliwej, choć korzystała $z$ wcześniejszych inspiracji, zwłaszcza Arystotelesa i Cycerona, została sformułowana przez Augustyna i Tomasza $z$ Akwinu. Stała się ona $z$ czasem najbardziej rozpowszechniona normatywna koncepcja wojny i pokoju. Tradycję teoretyczna wojny sprawiedliwej tworzyły tak wybitne postacie jak: Grocjusz, Suarez, Vattel i Vitoria, a dziś wpisuja się weń postacie tak znaczące jak John Rawls czy Michael Sandel.

Klasyczna grecka filozofia polityki za swój główny przedmiot uznawała dobre życie i jeśli zajmowała się prawem czy sprawied- 
liwością, to głównie w odniesieniu do dobrego życia. Sprawiedliwość była wówczas traktowana po prostu jako cnota pozwalająca dobrze żyć we wszystkich wymiarach - biologicznym, psychicznym oraz intelektualnym. Nie odnosiła się ona zasadniczo ani do prawa, ani tym bardziej do wojny. Także rzymska filozofia prawa nie znała pojęcia wojny sprawiedliwej. Rzymscy prawnicy opracowali natomiast pojęcie sprawiedliwości (iustitia) jako cnoty polegajacej na realizacji prawa (ius).

Wedle Rzymian - uważanych za twórców prawa - to, co przysługiwało danej osobie to ius. Nauce polegajacej na odkrywaniu tego, co się komu prawnie należało, nadano miano sztuki prawa (ars iuris). Cnota stałego postępowania wedle wymogów prawa uzyskała miano sprawiedliwości (iustitia) ${ }^{13}$. Wedle takiego ujęcia, akt sprawiedliwości był aktem wtórnym. Aktem pierwotnym było nadanie komuś jakiejś rzeczy i związanego $z$ nia prawa do jej posiadania, użytkowania, ochrony przed innymi. Cnota sprawiedliwości była więc następstwem istnienia prawa, następstwem uprzedniej w stosunku do prawa decyzji. Jeśli jednak coś zostało komuś przypisane, to uzyskał on do tego prawo ${ }^{14}$. Utrata tej rzeczy wymagała wyrównania - oddania mu, wedle sprawiedliwości, tego, co mu się prawnie należało. Cnota sprawiedliwości zakładała więc istnienie prawa, które ustanowione zostało aktem władczym. Sprawiedliwe stawało się działanie, które dążyło do oddania każdemu, co mu się należało, przy czym to, co komu się należało, określone zostało poprzez władczy akt.

Najczęściej pojęcie sprawiedliwości odnoszone było do relacji pomiędzy osobami - „oddaj każdemu, co mu się należy”, oznaczało wówczas nakaz zwrotu każdemu należnych mu przedmiotów, należnych tytułem własności czy też prawowitego posiadania (takich jak użyczenie, najem itp.). Były to relacje regulowane przez prawo cywilne. Starożytni nakaz oddawania każdemu, co mu się należy,

${ }_{13}$ J. Hervada, Prawo naturalne. Wprowadzenie, przekład A. Dorabialska, Wydawnictwo Petrus, Kraków 2011, s. 7.

${ }^{14}$ Ibidem, s. 15. 
odnosili także do relacji pomiędzy jednostką a wspólnota, które regulowało prawo publiczne. Zasadniczo jednak nie stosowano pojęcia sprawiedliwości do stosunków międzynarodowych, do wojny i pokoju, gdyż pod nieobecność prawa międzynarodowego trudno byłoby mówić o tym, co należne danej wspólnocie politycznej.

Augustyn jako pierwszy $z$ filozofów zbudował koncepcje polityki, której dominująca zasadą stał się pokój. Uznał, że jedynie wybrani moga realizować dobre życie, wspólnota polityczna zaś może co najwyżej opierać się na pokoju. W swej koncepcji „państwa bożego" Augustyn wskazał, że ludzkość została podzielona na dwa obozy: jeden $z$ nich tworzyły osoby kierujace się w swych działaniach wola Boga, drugi - osoby kierujące się w swych działaniach własną wolą. Co ważniejsze, w doczesnym życiu osoby realizujące obie postawy były nie do oddzielenia. Mimo radykalnego dualizmu postaw moralnych polityka musiała więc uwzględniać to, co ludzi łączyło - wartością wspólną dla obu postaw był pokój ${ }^{15}$. Pokój był bowiem wartością ludzka jednocześnie niesprzeczną $z$ boskim porządkiem; służył miłości własnej, pozostawał przy tym zgodny $z$ porządkiem duchowym.

W wymiarze fizycznym pokój pojmowany był jako brak bezpośredniej konfrontacji cielesnej, w wymiarze eschatologicznym - cień prawdziwego pokoju i jedności ogólnoludzkiego kosmosu. Pokój rozumiany jako brak agresji oraz równowaga sił stał się $\mathrm{w}$ interpretacji Augustyna właściwie jedynym zadaniem, które można było osiagnąc w najszerzej pojętej sferze politycznej. Dzięki uznaniu radykalnego dualizmu Augustyn jednocześnie opisywał ideę pokoju jako realistycznej równowagi sił pomiędzy jednostkami i zbiorowościami oraz ideę pokoju bożego ucieleśnionego w eschatologicznym kosmo-polis. W każdym ludzkim doświadczeniu porządki te nakładały się na siebie. Dlatego też każdy z opisów uspójniających polityczne doświadczenie okazywał się nieadekwatny. Mrzonki o realizacji kosmo-polis na ziemi natrafiały na mur złej woli, mogły

${ }_{15}$ Święty Augustyn, Państwo Boże, przekład W. Kubicki, Wydawnictwo Antyk - Marek Derewiecki, Kęty 2002, s. 776. 
nawet stawać się narzędziem przemocy wobec innych, prawidła działania zaś osadzone na egoizmie jako nieusuwalnej podstawie zderzały się $z$ równie realna postacią mistyka i świętego.

[...] odczuwamy jako zło niewatpliwe: podejrzenia, nieżyczliwość, walkę; a pokój tylko jako niepewne dobro, gdyż nie znamy serc ludzi, z którymi go utrzymywać chcemy; i choćbyśmy dziś je znali, to jakie one jutro będa, niepodobna nam, zaiste, wiedzieć $^{16}$.

Trudno tu było wskazać podstawy do myślenia teoretycznego w kategoriach sprawiedliwości. Każda bowiem teoria, zarówno zbudowana na założeniu egoizmu, jak i na założeniu altruizmu, byłaby niekompletna. W ten sposób Augustyn, przenoszac akcent w swej filozofii politycznej $z$ dobrego życia, którym od tej pory miała się zajmować teologia, na pokój, także wojnę odniósł do pokoju jako jej celu. Usprawiedliwiał on wojnę tylko wówczas, gdy służyła pokojowi. Nie zbudował jednak spójnej teorii wojny sprawiedliwej.

Jej autorem stał się Tomasz z Akwinu. Wracając do Arystotelesowskiej koncepcji dobrego życia, Tomasz uznał za Augustynem wojnę za stałe zagrożenie związane $z$ ludzka wolnością. Wyznaczył jej ramy, odwołujac się do kategorii prawa naturalnego. Wojna sprawiedliwa była przy tym ujęciu ochroną życia osób należących do zbiorowości, prowadzona w ograniczonym, wyznaczonym $z$ góry zakresie. Wedle Tomasza, głównym prawem natury była zasada nienaruszalności ludzkiego życia. Wojna sprawiedliwa stała na straży egzystencji całej zbiorowości. Źródłem życia i jedynym prawomocnym „dysponentem” życia był bowiem Bóg. $Z$ tego metafizycznego założenia wynikał $\mathrm{w}$ porządku indywidualnym zakaz samobójstwa i zabójstwa, w porządku zbiorowym, zakaz prowadzenia wojny i zarazem nakaz obrony zbiorowości przed zagrożeniami ze strony agresorów.

Tomaszowa koncepcja wojny sprawiedliwej została głęboko powiazana $z$ teologiczna koncepcja metafizyczną. Tomasz stwierdził, że rzeczy jednostkowe są zawsze złożone $z$ istoty $\mathrm{i}$ istnienia. Akwi-

${ }^{16}$ Ibidem, s. 769. 
nata wykorzystał przy tym pojęcie istoty $\mathrm{i}$ istnienia do uzasadnienia teologicznej koncepcji świata. W każdym bycie należało, jego zdaniem, odróżnić istotę, czyli to, czym dana rzecz była, od istnienia, czyli faktu, że zaistniała w tych konkretnych okolicznościach. Jedynym wyjątkiem był Bóg, który był samym istnieniem. Jego istota pociagała istnienie. Bóg był więc bytem koniecznym, ponieważ musiał istnieć; niezależnym, bo istniał $z$ własnej natury, oraz prostym, czyli nieposiadającym żadnych złożeń. Rzeczy stworzone były natomiast bytami przygodnymi, zależnymi od Boga oraz złożonymi. Zostały one niejako obdarzone istnieniem przez Boga.

Każda osoba, niezależnie od tego, czy była wierząca, czy też nie została obdarowana życiem. Żadnemu człowiekowi nie wolno więc było życia odbierać. $Z$ nauczania Tomasza wynikał jednoznaczny prawno-naturalny zakaz zabijania istot ludzkich. $Z$ nauczania tego wynikał także nakaz samoobrony. Poszanowanie autonomii Boga w odniesieniu do ludzkiego życia wymagało samoobrony zarówno indywidualnej, jak i zbiorowej. Jednostka zaatakowana przez napastnika miała nie tylko prawo, ale nawet obowiązek się bronić. Także zbiorowość, jeśli została zaatakowana, miała nie tylko prawo, ale i obowiązek bronić życie osób tworzacych tę zbiorowość.

Obrona zawsze odbywała się jednak w określonych granicach. Jej celem była ochrona życia. Współcześnie powiedzielibyśmy o granicach wyznaczonych ramami obrony koniecznej. Zarówno jednostka, jak i zbiorowość mogły podjąć w samoobronie tylko takie działania, które bezpośrednio służyły odparciu ataku, nie mogły natomiast przekraczać tych granic - a więc używać środków nadmiernych czy wynikających $z$ chęci zemsty.

W momencie gdy ochrona życia stawała się zadaniem władzy, Tomasz określał ja mianem siły miecza. W wymiarze indywidualnym siła miecza miała chronić te jednostki, które nie były w stanie bronić się same. Tomasz przyznawał władzy publicznej prawo karania zabójców. Kara traktowana była wówczas jako przywrócenie ładu naruszonego poprzez zbrodnię ${ }^{17}$. Argumenty przemawiające za kara

\footnotetext{
17 J. Finnis, Aquinas: Moral, Political and Legal Theory, Oxford University Press, Oxford 1998, s. 279.
} 
śmierci nie należały do porząlku utylitarnego, ale odwoływały się do ładu moralnego. Zarówno sprawiedliwość, jak i dobro wspólne zostały naruszone poprzez działanie osoby, która zadecydowała, że zabije niewinną istotę ludzka. Nakaz samoobrony w wymiarze zbiorowym - a więc prawo miecza - nakazywał $\mathrm{w}$ takim przypadku „trwałe zabezpieczenie” wspólnoty politycznej przed działaniem zabójcy. Oznaczało to karę śmierci, wówczas gdy nie było innych, mniej radykalnych form obrony zbiorowości przed morderca.

W wymiarze zbiorowym siła miecza chroniła zbiorowość polityczna przed atakiem ze strony innej zbiorowości. W przypadku agresji zaatakowana wspólnota miała nie tylko prawo, ale i obowiązek się bronić. Jednak, tak jak w przypadku wymierzania kary, także podczas wojny należało zachować granice obrony koniecznej. Akwinata zwracał uwage na przyczyny (iusta causa) właściwe dla rozpoczęcia wojny - musiała być ona rozpoczęta przez legitymowana władzę (auctoritas principis), zgodnie $z$ właściwymi intencjami (intentio recta).

W czasie wojny intencja powinno być powstrzymanie ataku. Każdy żołnierz był postrzegany jako członek wrogiej armii. $Z$ chwila jednak kiedy się poddawał, winien być wzięty do niewoli - wojna prowadzona bez brania jeńców byłaby więc niesprawiedliwym sposobem walki ${ }^{18}$.

Siła miecza, a więc także prawo prowadzenia wojny były właściwe dla władzy publicznej. Osoba prywatna mogła zostać zaangażowana do udziału w wymierzaniu kary bądź prowadzeniu wojny, zasadniczo jednak aktywność ta leżała w gestii publicznego autorytetu ${ }^{19}$. Autorytet publiczny oznaczał występowanie w imieniu całej wspólnoty i został ostatecznie związany z legalna władzą.

W kwestii 40. Sumy teologicznej czytamy:

Aby jakaś wojna była sprawiedliwa, musi odpowiadać trzem warunkom. 1. Władza książęca (auctoritas principis), z której polecenia wojna ma być prowadzona. Osoba bowiem prywatna nie jest władna wypowiadać wojny, bo swych praw może dochodzić przed trybunałem władzy. [...]

18 Ibidem, s. 287.

${ }^{19}$ Ibidem, s. 275. 
2. Drugim warunkiem jest słuszność sprawy (causa iusta), by mianowicie strona, przeciw której wojna ma być prowadzona, zasłużyła na to jakąs przewina. [...]

3. Ze strony walczących ma być uczciwy zamiar (intentio recta): a więc dla poparcia dobra lub uniknięcia $z^{2}{ }^{20}$.

W ten sposób, dzięki Tomaszowi, zostały sformułowane ramy późniejszego prawa wojennego. Teoria wojny sprawiedliwej została podzielona na trzy części, które także w literaturze zachowały łacińskie nazewnictwo. Na teorię wojny sprawiedliwej do dziś składają się następujące warunki:

- Ius ad bellum - wojna sprawiedliwa to wojna, do której strona przystępuje zgodnie $z$ prawem;

- Ius in bello - wojna sprawiedliwa to wojna, która jest toczona zgodnie $z$ wymaganiami ograniczenia działań zbrojnych;

- Ius post bellum - ostatni, najnowszy dział prawa międzynarodowego obejmujący regulacje, które mają służyć stabilizacji po wojnie.

\section{Zasady ius ad bellum}

Zasady prawa do wojny dotyczyły przede wszystkim legalnej władzy. Wskazywały, że w każdym państwie powinna być osoba upoważniona do podejmowania decyzji o przystapieniu do wojny i ponosząca odpowiedzialność, także karną, za wszczęcie wojny niesprawiedliwej. Dla Tomasza $z$ Akwinu równie ważne było, aby władza ta nie tylko była legitymizowana poprzez formalne prawo, ale także istotnie występowała w imieniu całego ludu ${ }^{21}$.

\footnotetext{
${ }^{20}$ Tomasz z Akwinu, Traktat Miłość, Zagadnienie 40, O wojnie, w: Suma teologiczna. Miłość, t. 16, tłum. A. Głażewski, „Veritas”, Londyn 1967, s. 152-153.

${ }^{21}$ Rekonstrukcja zasad wojny sprawiedliwej odpowiada współczesnym regulacjom prawnym w tym zakresie, jakie tworza między innymi konwencje genewskie (1949): o polepszeniu losu rannych i chorych $\mathrm{w}$ armiach czynnych na lądzie, o polepszeniu losu rannych, chorych i rozbitków sił zbrojnych na morzu, traktowaniu jeńców wojennych oraz o ochronie osób cywilnych podczas wojny; Konwencja o zakazie doskonalenia, produkowania i przechowywania broni biologicznej i toksycznej oraz o ich zniszczeniu (1972); dwa Protokoły dodatkowe do konwencji genewskich, wzmacniajace ochronę ofiar konfliktów zbrojnych o charakterze międzynarodowym (I Protokół) i niemiędzynarodowych (II Protokół) (1977); Konwencja o za-
} 
- Prawo umożliwia władzy legitymowanej przystapienie do wojny ze sprawiedliwych powodów (iusta causa). Sprawiedliwym powodem jest działanie $\mathrm{w}$ samooobronie, ale także $\mathrm{w}$ obronie sojuszników.

- Słuszna intencja - intentio recta. Legitymowana władza może wypowiedzieć wojnę jedynie wówczas, gdy kieruja nia słuszne intencje. Nie wystarczy formalna "słuszna przyczyna”, także faktycznym, realnym powodem podjęcia decyzji o wojnie winna być obrona lub obrona sojuszników.

- Właściwa władza i publiczna deklaracja. Państwo może podjać decyzję o wojnie, tylko zgodnie $z$ wewnętrznymi procedurami, przez właściwe władze, a decyzja ta winna zostać podana do publicznej wiadomości.

- Wyczerpanie pozostałych środków. Państwo może uciekać się do wojny tylko wtedy, gdy wyczerpało wszelkie inne pokojowe środki służące rozwiązaniu problemu.

- Prawdopodobieństwo sukcesu. Warunek ten nie został wprawdzie uwzględniony $\mathrm{w}$ prawie międzynarodowym, ale wynika $z$ teoretycznych ram koncepcji wojny sprawiedliwej. Skoro wojna ma na celu obronę obywateli przed agresja, to nie spełnia tego wymogu akcja zbrojna $z$ góry uznana za bezskuteczna.

- Proporcjonalność. Zgodnie z zasada proporcjonalności szkody powinny być proporcjonalne do skutków, które zamierza się uzyskać.

Pierwsze trzy warunki miały charakter obiektywny: określały formalny charakter decyzji o wypowiedzeniu wojny oraz jej powód, nie tylko formalny, ale także będący rzeczywista przyczyną decyzji o wojnie. Kolejne trzy warunki wskazywały na konsekwencje, które winny zostać wzięte pod uwage już w momencie podejmowania decyzji o przystapieniu do wojny.

kazie używania technicznych środków oddziaływania na środowisko $\mathrm{w}$ celach militarnych lub jakichkolwiek wrogich celach (1977); Konwencja o zakazie lub ograniczeniu używania pewnych broni konwencjonalnych, które mogą być uważane za powodujące nadmierne cierpienia lub posiadające niekontrolowane skutki (1980) oraz: protokół I - o niewykrywalnych odłamkach, protokół II - o zakazie lub ograniczeniu min, min pułapek itp., protokół III o zakazie lub ograniczeniu używania broni zapalających; Konwencja o zakazie doskonalenia, produkowania i przechowywania broni chemicznej oraz o jej zniszczeniu (1993). 


\section{Ius in bellum}

Zasady ograniczające użycie sił zbrojnych w trakcie wojny dotyczyły przede wszystkim samych walczacych armii. Odpowiedzialność spoczywała tu na dowódcach, oficerach i żołnierzach, czyli na konkretnych osobach, podejmujacych decyzje o sposobach prowadzenia walki. Zasady ograniczające użycie sił zbrojnych nazywane były także zasadami prawa konfliktów zbrojnych bądź prawem humanitarnym.

Główne zasady prawa konfliktów zbrojnych:

- Obowiązek odróżniania uczestników walki zbrojnej od ludności cywilnej. Oznacza to, że ludność cywilna, jak i poszczególne osoby cywilne nie powinny być przedmiotem ataków wojskowych. Ataki powinny być skierowane wyłacznie na cele wojskowe (wojna to stosunek między państwami, a nie między ich ludnością cywilna).

- Zakaz zabijania lub ranienia przeciwnika poddającego się lub wyłączonego $z$ walki (ochrona jeńców wojennych).

- Obowiazek zabierania $z$ pola walki i leczenia rannych oraz chorych. Obliguje to stronę konfliktu, pod władza której się znajduja, do ochrony rannych i chorych oraz do ich poszanowania.

- Ograniczenie metod oraz środków walki zbrojnej. Zakazane sa niektóre rodzaje broni (broń chemiczna i biologiczna). Wprawdzie nie ma jednoznacznego zakazu stosowania broni nuklearnej, ale nie spełnia ona kolejnego wymogu, jakim jest proporcjonalność.

- Proporcjonalność. Żołnierze winni używać tylko takich metod i środków walki zbrojnej, które sa proporcjonalne do celu działań zbrojnych. Broń masowego rażenia na przykład jest zazwyczaj postrzegana jako niewspółmierna do zadań militarnych.

- Żołnierze nie moga używać broni lub metod, które sa „złe same w sobie". Nie wolno więc stosować ludobójstwa, czystek etnicznych, używać trucizny lub dopuszczać się zdrady. 


\section{Ius post bellum}

Ius post bellum odnosiło się do wymiaru sprawiedliwości w trzecim i ostatnim etapie wojny, czyli do jej zakończenia. Prawo ładu powojennego stało się zwłaszcza w ostatnich latach przedmiotem wielu badań $z$ zakresu filozofii polityki.

- Proporcjonalność. Porozumienie pokojowe powinno uwzględniać rozsądne warunki i zostać publicznie ogłoszone. Skoro bowiem ogłoszenia wymaga wypowiedzenie wojny, to także jej zakończenie winno być aktem jawnym, formalnie poprawnym i rozsądnym. Przez "rozsądek” warunków pokojowych rozumie się to, że nie sa to warunki wynikajace $z$ zemsty, nienawiści i moga stać się podstawa stabilnego pokoju.

- Prawa człowieka do życia, wolności osobistej i politycznej powinny stać się podstawą ładu, który winien uwzględniać również prawa zbiorowości do suwerenności i nienaruszalności terytorialnej.

- Odpowiedzialność. Powinno się rozróżniać stopnie odpowiedzialności za wojnę pomiędzy przywódcami politycznymi, przywódcami wojskowymi a zwykłymi żołnierzami i ludnością cywilną. Ludność cywilna nie powinna być karana za wojnę. W zasadzie wyklucza to stosowanie sankcji gospodarczych jako kar powojennych.

- Przywódcom i osobom odpowiedzialnym za wojnę należy umożliwić uczciwy międzynarodowy proces.

- Karani powinni być wszyscy, którzy dopuścili się zbrodni wojennych, zarówno po stronie, która wygrała konflikt, jak i po stronie pokonanej.

- Kwestia sporna jest możliwość narzucania stronie pokonanej systemu sprawowania władzy czy przebudowy ustrojowej.

Teoria wojny sprawiedliwej jest obecnie główna podstawa regulacji prawnych w stosunkach międzynarodowych, stanowi również dominujace stanowisko teoretyczne wśród współczesnych teoretyków i badaczy. Zwolennikami teorii wojny sprawiedliwej sa tacy autorzy jak: Murray Rothbard, Michael Novak, Michael Walzer, Robert L. Holmes, Jean Bethke Elshtain, Oliver O’Donovan, George Weigel, Jeff McMahan i Brian Orend. 
Także najbardziej znany współczesny filozof polityki John Rawls przyjął teorię wojny sprawiedliwej. Właściwie powtórzył on, zgodnie $z$ tradycja, sprawiedliwe powody przystapienia do wojny. Przyznał wszystkim ludom prawo do wojny obronnej oraz prawo do wojny $\mathrm{w}$ obronie sojuszników. Interesujące natomiast okazało się Rawlsowskie zestawienie ius in bellum, gdyż w tej kategorii filozof uwzględnił zarówno klasyczne prawa dotyczace prowadzenia konfliktów zbrojnych, jak i nowe interpretacje uwzględniające ius post bellum. Dodatkowo Rawls dopuścił swoisty „propagandowy” wymiar wojny. Celem wojny miał być sprawiedliwy pokój, przy czym, według Rawlsa, w efekcie wojny jak najwięcej państw oraz społeczeństw powinno przestrzegać praw człowieka ${ }^{22}$.

- Celem sprawiedliwej wojny jest sprawiedliwy i trwały pokój między ludami, a w szczególności pokój z jego aktualnym wrogiem.

- Ludy dobrze urządzone nie prowadza wojen między soba, a jedynie przeciwko państwom niedobrze urządzonym, których ekspansjonizm zagraża bezpieczeństwu i wolnym instytucjom ustrojów dobrze urządzonych i które sa przyczyną wojny.

- W prowadzeniu wojny ludy dobrze urządzone musza uważnie rozgraniczać trzy grupy: przywódców i wyższych urzędników państwa bezprawnego, jego żołnierzy i ludność cywilną. Cywilni członkowie społeczeństwa nie moga być bowiem, według Rawlsa, traktowani na równi $z$ tymi, którzy zorganizowali i wywołali wojnę. Zrobili to przywódcy i wyżsi urzędnicy. To oni sa odpowiedzialni, oni podjęli decyzję o niesprawiedliwej wojnie i prowadząc ją, stali się przestępcami. Także żołnierze nie są odpowiedzialni za wojnę, pochodza w większości $z$ poboru i nie ponosza odpowiedzialności za decyzję o wojnie. Zostali zindoktrynowani, często wykorzystuje się ich patriotyzm.

- Nawet w czasie walki należy przestrzegać (maksymalnie) praw człowieka, gdyż jest to najskuteczniejszy sposób ich propagowania.

22 J. Rawls, Prawo ludów, przekład Michał Kozłowski, Fundacja Aletheia, Warszawa 2001, s. 138 . 
- Ludy dobrze urzadzone powinny zapowiadać zarówno rodzaj pokoju, do jakiego dążą, jak i stosunków władzy, które propagują. Obowiązkiem męża stanu jest zawsze postępowanie najwłaściwsze w jak najdalszej perspektywie.

- Normy prowadzenia wojny ustanawiaja granice dla realizacji własnych interesów ${ }^{23}$.

Zwłaszcza w czwartej i piątej zasadzie Rawls uwzględnił ius post bellum. Prawa po wojnie czy też reguły sprawiedliwego pokoju powinny bowiem prowadzić do ustanowienia trwałego pokoju, bezpiecznego w możliwie długiej perspektywie. Autorska propozycja Rawlsa polegała tu na tym, aby ius post bellum było realizowane nie na drodze prawa międzynarodowego, ale odpowiedzialności politycznej „mężów stanu”. W odróżnieniu od tradycyjnych ujęć wojny sprawiedliwej taka odpowiedzialność nie miała charakteru odpowiedzialności formalnej, nie istniał bowiem urząd męża stanu. Mężowie stanu byli prezydentami, premierami lub wysokimi urzędnikami, którzy przez swe wzorowe zachowanie i sprawowanie urzędu demonstrowali siłę, odwagę i mądrość. Przewodzili swojemu ludowi w czasie zawirowań i niebezpieczeństw. „Polityk myśli o następnych wyborach, mąz stanu o następnym pokoleniu" ${ }^{24}$. Takie osoby nie mogły, zdaniem Rawlsa, kierować się, zwłaszcza w czasie wojny, żądzą zemsty. „Nade wszystko mężowie stanu powinni być mocno przywiązani do idei osiagnięcia sprawiedliwego pokoju i unikać wszystkiego, co może utrudnić jego realizację"25.

Ponadto Rawls zwrócił uwagę na bardzo istotny element związany $z$ tradycja wojny sprawiedliwej. Był to bowiem szkielet prawa międzynarodowego oparty na często dziś odrzucanych rozważaniach natury metafizycznej. Tradycja wojny sprawiedliwej mogła, zdaniem Rawsla, zostać oparta na idei praw człowieka i zaakceptowana szeroko mimo różnic politycznych oraz ideologicznych. Ponadto, aby była żywa, wymagała edukacji obywatelskiej i stałej

${ }^{23}$ Ibidem, s. 138-142.

${ }^{24}$ Ibidem, s. 142.

${ }^{25}$ Ibidem, s. 143. 
obecności w przestrzeni publicznej. Sprawiedliwe zasady przystępowania do wojny, prowadzenia wojny oraz ustanawiania pokoju powinny się stać stałym elementem międzynarodowej kultury politycznej. W ten sposób także najbardziej wpływowy współczesny filozof polityki, odrzucajac metafizyczne zaplecze teorii wojny sprawiedliwej, zaakceptował ja jako najlepsza teorię normatywna, która winna porządkować zasady prawa międzynarodowego,

Cała teoria wojny sprawiedliwej, od swych początków po prace Rawlsa, opierała się jednak na wspólnotowej ontologii - jej podmiotem były całe zbiorowości czy, jak powiadał Rawls, ludy, które miały armię, oficjalna reprezentację polityczną, mężów stanu i zwykłych obywateli. Problem komplikował się, gdy ta wspólnotowa ontologia polityczna została zakwestionowana. Tymczasem właśnie wojny nowego typu nie pozwalały się w nią wpisać. W efekcie odejścia od zbiorowej ontologii w stronę języka odwołującego się do pojęcia hegemonii, jak to się stało w odniesieniu do wojny nowego typu, uzyskano całkowicie nieprzejrzysty obraz stosunków zarówno wewnętrznych, jak i zewnętrznych. Do tak opisanej rzeczywistości nie mogła mieć zastosowania teoria wojny sprawiedliwej, która została zbudowana w odniesieniu do jednolitych i skonsolidowanych wspólnot politycznych, w których można było wyróżnić legitymowaną władzę, porządek decyzyjny, pozwalajacy określić zakres odpowiedzialności za podejmowane decyzje, wreszcie - oficjalne armie i publicznie toczone walki, wskazujace na różnice pomiędzy wojskowymi i cywilami, walka i pokojem. Tymczasem w teorii wojny nowego typu wszystkie te elementy zostały zakwestionowane.

$Z$ tego też powodu współcześnie wielu autorów usiłowało odbudować słownik, który pozwalałby opisać, ale zarazem uporządkować ład - także wojenny, odwołując się do innych pojęć niż pojęcia suwerenności. $Z$ perspektywy przeprowadzonej rekonstrukcji nasuwa się wniosek, że podstawa nowej rekonstrukcji nie mogły być jakiekolwiek koncepcje metafizyczne. Także język realizmu politycznego, odwołujący się do hegemonii, nie budował 
nowego ładu. Skoro język metafizyki został odrzucony przez większość teoretyków, jego miejsce mógł wprawdzie zająć język prawa. Wymagał on jednak przeformułowania wspólnoty politycznej, tak aby nie odwoływała się jedynie do kategorii państwa jako swojej podstawy, ale uwzględniała również kryzys pojęcia suwerenności. Także naga, pozbawiona normatywnego modelowania siła niczego nie porządkowała i nie mogła porządkować. Ponadto koncepcja wojny sprawiedliwej i oparte na niej prawo międzynarodowe praktycznie przestały obowiazywać $\mathrm{w}$ odniesieniu do wojen nowego typu. Wszystkie te przemiany wskazywały, że rozpadały się dotychczasowe formy wspólnotowości politycznej zorganizowanej wokół instytucji państwa, czemu towarzyszył chaos nakładających się na siebie stosunków ekonomicznych i politycznych. Tymczasem bez wspólnoty, władzy i hierarchii nie można było mówić także o prawnych aspektach wojny, odpowiedzialności za wojnę ani o przyszłej wizji pokoju. Być może wniosek $z$ tych analiz jest niezwykle skromny, ma on jednak także znaczące konsekwencje. Prawo międzynarodowe - zwłaszcza ta jego część która odnosi się do wojen - wymaga jednoznacznie określonych podmiotów tego prawa. Wojna nowego typu taka podmiotowość zaciera i rozwarstwia. Nie można jednak porzucić prawa konfliktów zbrojnych, gdyż konsekwencje takiego porzucenia byłyby gorsze niż dotychczasowe problemy zwiazane $z$ pozbawiona podstawy politycznej teoria wojny sprawiedliwej. Teoria ta może bowiem stanowić oparcie dla prawa konfliktów zbrojnych, gdy usuniemy jej metafizyczne uzasadnienia. Poza tym nie widać żadnej poważnej teorii konkurencyjnej. Teoria wojny sprawiedliwej wymaga jednak określonych podmiotów zbiorowych. Pozostaje mieć nadzieję, że dotychczasowe formy wspólnotowości przekształcaja się, co doprowadzi do wyłonienia się form nowych, w odniesieniu do których znów będzie można zastosować narzędzia teoretyczne oraz prawne zwiąane $z$ koncepcją sprawiedliwości. 